\title{
FUNGSI PENGAWASAN DEWAN PERWAKILAN RAKYAT DAERAH TERHADAP PELAKSANAAN PERATURAN DAERAH MENGENAI ANGGARAN PENDAPATAN DAN BELANJ A DAERAH DI KABUPATEN BATANG
}

\author{
Benny Abidin'1, Ratna Herawati² \\ Program Studi Magister Ilmu Hukum \\ Fakultas Hukum Universitas Diponegoro \\ J alan Imam Bardjo, S.H. No. 1-3, Kampus Pleburan, Semarang 50241 \\ bennybatang09@yahoo.co.id
}

\begin{abstract}
Implementation of the Regional Budget Regional Regulation of the Batang Regency in the 2016 period from the supervision side of the DPRD as a partner of the Regional Head as the implementation of regional government in the era of regional autonomy based on Law No. 23 of 2014 concerning Regional Government. The paper discusses analyzing the DPRD's supervisory patterns on APBD regulations which have implications for the achievement of regional development goals in accordance with regional development planning regulations (RPJPD / RPJMD). The research method used is normative juridical by using secondary data consisting of primary legal materials and secondary legal materials as well as qualitative data analysis. Supervision of the Batang District DPRD against the Regional Budget Regulation has not run optimally due to the supervisory function of the Batang DPRD dominated by technical-functional supervision rather than political supervision. Polla oversees the Batang DPRD not oriented to the vision and mission, development goals and objectives of Batang 2012-2017. Factors influencing the supervision of the Batang DPRD on the implementation of the Batang 2016 Regional Budget Regional Regulation are legal factors, law enforcement officers, facilities and infrastructure facilities for law enforcement and community factors (Culture). The legal factor itself has been able to create effective DPRD supervision conditions. Factors of law enforcement officers, facilities and infrastructure facilities for law enforcement and community factors (Culture) are still an obstacle to the supervision of the Batang DPRD on the implementation of the Batang 2016. APBD Regional Regulations has not been used well in the pattern of performance-based budgeting, the implementation of performance-based culture has not been optimal and the mechanism of community participation in planning and budgeting is not yet available.
\end{abstract}

Keywords : Regional autonomy; Check and Balances; Good governance; Supervision.

\begin{abstract}
ABSTRAK
Implementasi Perda APBD Kabupaten Batang pada periode 2016 dari sisi pengawasan DPRD sebagai mitra Kepala Daerah sebagai penyelenggaraan pemerintahan daerah pada era otonomi daerah berdasarkan Undang-Undang No. 23 Tahun 2014 tentang Pemerintahan Daerah. Tulisan membahas dan menganalisa pola pengawasan DPRD terhadap perda APBD yang memiliki implikasi tercapainya tujuan pembangunan daerah sesuai dengan perda perencanaan pembangunan daerah (RPJPD/RPJMD). Metode penelitian yang digunakan yuridis normatif dengan menggunakan data
\end{abstract}

\footnotetext{
${ }^{1}$ Anggota DPRD Kabupaten Batang

2 Dosen Program Studi Magister IImu Hukum Universitas Diponegoro
} 
sekunder yang terdiri bahan hukum primer dan bahan hukum sekunder serta analisa data bersifat kualitatif. Pengawasan DPRD Kabupaten Batang terhadap Perda APBD belum berjalan maksimal yang disebabkan fungsi pengawasan DPRD Kabupaten Batang lebih didominasi pengawasan teknisfungsional daripada pengawasan politik. Polla pengawasan DPRD Kabupaten Batang belum berorientasi pada visi-misi, tujuan dan sasaran pembangunan Kabupaten Batang 2012-2017. Faktorfaktor yang mempengaruhi pengawasan DPRD Batang terhadap pelaksanaan Perda APBD Batang 2016 adalah faktor hukum, aparat penegak hukum, fasilitas dan sarana prasarana penegakan hukum dan faktor masyarakat (Budaya). Faktor hukum sendiri telah dapat menciptakan kondisi pengawasan DPRD berjalan efektif. Faktor aparat penegak hukum, fasilitas dan sarana prasarana penegakan hukum dan faktor masyarakat (Budaya) masih menjadi menjadi penghambat pengawasan DPRD Batang terhadap pelaksanaan Perda APBD Batang 2016. Hambatan-hambatan tersebut adalah belum terjalin koordinasi dan sinergi antar aparat pengawasan fungsional dan DPRD Kabupaten Batang, belum digunakan dengan baik pola penganggaran berbasis kinerja, belum optimalnya penerapan budaya berbasis kinerja dan belum tersedianya mekanisme partisipasi masyarakat dalam perencanaan dan penganggaran.

\section{Kata Kunci: Otonomi Daerah; Checkand Balances; Good Govemance; Pengawasan.}

\section{A. Pendahuluan}

Momentum otonomi daerah di Indonesia semakin mendapatkan tempatnya setelah MPR RI melakukan amandemen pada Pasal 18 UUD 1945 dalam perubahan kedua yang secara tegas dan eksplisit menyebutkan bahwa negara Indonesia memakai prinsip otonomi dan desentralisasi kekuasaan politik. Undang-Undang Dasar 1945 pasal 18 ayat 2 secara tegas menyebutkan Pemerintah daerah provinsi, daerah Kabupaten, dan Kota mengatur dan mengurus sendiri urusan pemerintahan menurut asas otonomi dan tugas pembantuan (Andriana, 2014).

Penyelenggaraan otonomi daerah didukung penyediaan sumber-sumber pembiayaan berdasarkan desentralisasi, dekonsentrasi, tugas pembantuan (Nurhemi \& Suryani R, 2015), dan instansi vertikal perlu diatur perimbangan keuangan antara pemerintah pusat dan daerah berupa sistem keuangan yang diatur berdasarkan pembagian wewenang, tugas dan tanggung jawab yang jelas antar tingkat pemerintahan (Budiyono, 2013) yang mempunyai implikasi diskresi luas pada aspek pengelolaan keuangan daerah sebagaimana diatur dalam Undang-Undang Nomor 33 Tahun 2004 yang cenderung mengurangi kooptasi dan intervensi pemerintah pusat terhadap pengelolaan keuangan daerah (Amalia, 2011).

Diskresi menyebabkan pemerintah daerah dapat menentukan pengeluarannya sesuai dengan kebutuhan dan prioritas daerah. Untuk itu penyelenggaraan Pemerintah Daerah dalam rangka otonomi daerah memerlukan inovasi dalam bidang Pemerintahan secara keseluruhan (Suryanto, 2010). Sudah waktunya untuk dipikirkan bagi kepentingan pemerintahan masa depan sebuah pola interaksi antara eksekutif dengan legislatif didaerah dengan menciptakan 
mekanisme Checks and Balances tingkat local (Kumorotomo, 2007).

Posisi DPRD Dalam Undang-Undang Nomor 23 Tahun 2014 tentang Pemerintahan Daerah memiliki posisi strategis dan menentukan keberhasilan dan kegagalan pembangunan daerah (Lusiah \& Rajagukguk, 2011). DPRD merupakan lembaga perwakilan rakyat daerah dan berkedudukan sebagai unsur penyelenggaraan pemerintahan daerah yang memiliki fungsi legislasi, anggaran dan pengawasan (Fitriyah, 2010) Fungsi Anggaran yang ada bersama kepala daerah menyusun serta menetapkan Anggaran Pendapatan yang ada atau Belanja Daerah (APBD) tiap tahun ke tahun. Fungsi anggaran tersebut disertai fungsi pengawasan terhadap Peraturan Daerah APBD yang telah ditetapkan. Menurut UU Nomor 17 Tahun 2014 Tentang Majelis Permusyawaratan Rakyat, Dewan Perwakilan Rakyat,Dewan Perwakilan Daerah, Dan Dewan Perwakilan Rakyat Daerah, Bab VI Bagian Kedua Pasal 366 Ayat 1 (c) yang burbunyi, "DPRD Kabupaten/Kota Memiliki Tugas dan Wewenang melaksanakan pengawasan terhadap pelaksanaan peraturan daerah dan anggaran pendapatan dan belanja daerah kabupaten/kota".

Fungsi pengawasan DPRD terhadap jalannya penyelengaraan pemerintah daerah telah diimplementasikan secara efektif dalam hubungan kepala daerah dan DPRD yang setara, tidak saling menjatuhkan dan bermitra untuk menghasilkan kebijakan penyelenggaraan pembangunan daerah yang lebih baik (Amalia, 2011) Namun demikian fungsi pengawasan DPRD belum berjalan maksimal untuk dapat mencapai misi dan tujuan yang ditetapkan pemerintah daerah. Hubungan kesetaraan dan kemitraan DPRD dan Kepala Daerah dalam pengembilan kebijakan daerah masih diwarnai dengan masih banyaknya kasus korupsi, kolusi, dan nepotisme dalam penyelenggaraan pemerintah daerah. Berdasarkan data BPKP yang diolah dari laporan tahun 2012 sampai dengan tahun 2015 menunjukkan terdapat 71 perkara tindak pidana korupsi TPK di instansi pemerintah provinsi, sementara itu di Kabupaten / Kota terdapat107perkaraTPK(http://uwww.bpkp.go.id/pu slitbangwas/konten/2674/16.050-Faktor-FaktorPenyebab-Kepala-Daerah-Korupsi, diakses 16 Juni 2018). Mayoritas motif tindak pindak korupsi tersebut adalah suap dan gratifikasi yang melibatkanDPRD,KepaladaerahdanPengusaha(ht tp://www.bpkp.go.id/puslitbangwas/konten/2674/1 6.050-Faktor-Faktor-Penyebab-Kepala-DaerahKorupsi, diakses 16 Juni 2018). Hal ini disebabkan kepala daerah memiliki kekuasaan yang sangat besar dalam pengelolaan anggaran APBD, perekrutan pejabat daerah, pemberian ijin sumber daya alam, pengadaan barang dan jasa dan pembuatan peraturan kepala daerah

Diberlakukannya Undang-Undang Nomor 23 Tahun 2014, akan merubah pola pemakaian dana daerah, mengingat diskresi yang luas yang diberikan oleh pusat kepada daerah dalam pemanfaatan anggaran daerah sekalipun dana 
tersebut berasal dari pusat. Daerah akan melakukan pemanfaatan anggaran sesuai dengan kebutuhan dan prioritas daerah. Kebutuhan dan prioritas daerah akan erat hubungannya dengan visi dan misi yang dikembangkan oleh daerah yang bersangkutan. Untuk itu maka sasaran dari pengawasan anggaran adalah sejauh mana keterkaitan antara alokasi anggaran dengan pencapaian visi dan misi daerah.

Berdasarkan uraian tersebut, maka penulis tertarik untuk mengadakan penelitian tentang: "Fungsi Pengawasan Dewan Perwakilan Rakyat Daerah Terhadap Pelaksanaan Peraturan Daerah Mengenai Anggaran Pendapatan Dan Belanja Daerah Di Kabupaten Batang". Melalui tulisan ini diharapkan mampu pengetahuan yang teruji kebenarannya melalui proses penelitian dan analisis tentang Fungsi Pengawasan DPRD Terhadap Pelaksanaan Perda (Peraturan Daerah) APBD Oleh Pemerintah Daerah Kabupaten Batang. Fungsi pengawasan DPRD sebagai sarana cheek and balance serta diharapkan agar fungsi pengawasan yang dilakukan oleh DPRD untuk memperkuat akuntabilitas pemerintahan daerah untuk mewujudkan good governance. Penelitian terdahulu mayoritas menncermati dan menganalisis tentang pelaksanaan pengawasan DPRD dari dari satu sisi saja yakni implementasi kebijakan yang dilihat dari perspektif administrasi publik, sedangkan penelitian ini berusaha mengkaji dari dua sisi yakni adminitrasi public dan hukum.

\section{B. Metode Penelitian}

Penelitian hukum adalah suatu proses untuk menemukan aturan hukum, prinsip-prinsip hukum, maupun doktrin-doktrin hukum guna menjawab isu hukum yang dihadapi (Marzuki, 2011). Metode penelitian hukum adalah sebagai cara kerja ilmuan yang salah satunya ditandai dengan penggunaan metode. Secara harfiah mula-mula metode diartikan sebagai suatu jalan yang harus ditempuh menjadi penyelidikan atau penelitian yang berlangsung menurut suatu rencana tertentu (Ibrahim, 2006).

\section{Pembahasan}

Konsepsi pengawasan DPRD meliputi pemahaman tentang makna dan arti penting pengawasan, ruang lingkup dan proses pengawasan (Aminudin, 2015). Pengawasan merupakan salah satu fungsi manajemen untuk menjamin pelaksanaan kegiatan sesuai dengan kebijakan dan rencana yang telah ditetapkan serta memastikan tujuan dapat tercapai secara efektif dan efisien. Dalam konteks membangun manajemen pemerintahan publik yang bercirikan good governance pengawasan merupakan aspek penting untuk menjaga fungsi pemerintahan berjalan sebagaimana mestinya.

Pengawasan adalah proses dalam menetapkan ukuran kinerja dan pengambilan tindakan yang dapat mendukung pencapaian hasil yang diharapkan sesuai dengan kinerja yang telah ditetapkan tersebut. Controlling is the process of measuring performance and taking action to ensure desired results (Schermerhorn, 2002). 
Pengawasan adalah proses untuk memastikan bahwa segala aktifitas yang terlaksana sesuai dengan apa yang telah direncanakan. The process of ensuring that actual activities conform the planned activities (Stoner, Freeman \& Gilbert, 2005).

Keputusan Presiden RI No. 74 tahun 2001 (tentang tata cara pengawasan penyelenggaraan pemerintah daerah) pasal 1 ayat 6 menyebutkan bahwa pengawasan pemerintah daerah adalah proses kegiatan yang ditujukan untuk menjamin agar pemerintahan daerah berjalan sesuai dengan rencana dan ketentuan peraturan perundang-undangan yang berlaku. Pengawasan penyelenggaraan pemerintahan daerah terdiri atas pengawasan fungsional, pengawasan legislatif dan pengawasan masyarakat (Keputusan Presiden Nomor 74 tahun 2001 Pasal 2)

Pengawasan yang dilakukan oleh DPRD merupakan pengawasan legislatif (Politik) yang mengharuskan anggota-anggota DPRD melakukan langkah-langkah nyata untuk melakukan pengawasan terhadap kinerja pemerintah daerah atas nama masyarakat yang telah memilihnya. Ruang lingkup pengawasannya meliputi seluruh siklus angaran, mulai dari tahap perencanan, pelaksanaan, dan pertangungjawaban. Fungsi pengawasan DPRD bertujuan untuk memastikan seluruh kebijakan publik yang terkait dengan siklus angaran dilaksanakan sesuai dengan peraturan perundang-undangan yang berlaku dan berorientasi pada prioritas publik. Pengawasan DPRD bukan merupakan bentuk pemeriksaan (auditor) pengeloalaan dan pertanggungjawaban APBD namun lebih mengarah pada pengawasan untuk menjamin pencapaian sasaran yang telah ditetapkan dalam dokumen perencanaan dan penganggaran. Seperti yang dijelaskan dalam Peraturan Pemerintah Nomor 58 tahun 2005 tentang Pengelolaan Keuangan Daerah pada Pasal 132 DPRD melakukan pengawasan terhadap pelaksanaan Peraturan Daerah tentang APBD.

Menganalisa dan membahas pengawasan DPRD Batang Tahun 2016 dalam implementasi pengawasan APBD dikelompokan pada tahap perencanaan, tahap pelaksanaan APBD dan tahap evaluasi

\section{Tahap Perencanaan}

Proses perencanaan dan penganggaran Kabupaten Batang 2016 yang dimulai dari rancangan awal RKPD 2016 yang merupakan penjabaran RPJMD Kabupaten Batang 20122017 tahun ke 5 belum dapat dimanfaatkan dengan baik oleh DPRD Kabupaten Batang. Peraturan Menteri Dalam Negeri No 54 Tahun 2010 yang merupakan peraturan pelaksanan dari UU SPN memberikan kesempatan DPRD Kabupaten Batang untuk dapat memasukan pokok-pokok pikiran DPRD (Pokir DPRD) tidak dimanfaatkan untuk melaksanakan fungsi pengawasan. DPRD Kabupaten Batang lebih cenderung menggunakan Permendagri No. 54 Tahun 2010 tentang pelaksanaan PP No. 98 
Tahun 2008 tentang tahapan, tata cara penyusunan pengendalian dan evaluasi pelaksanaan rencana pembangunan daerah, untuk dapat memasukan usulan-usulan kegiatan ke dalam program-program pembangunan daerah ke dalam RKPD 2016.

Demikian pula dalam tahap penganggaran APBD Kabupaten Batang Tahun 2016 yang diawali dengan penyusunan Kebijakan Umum Anggaran dan penentuan prioritas plafon anggaran sementara (PPAS) yang dibahas bersama antara Tim TPAD yang merupakan Wakil dari Kepala Daerah (eksekutif) dan Tim Banggar DPRD tidak dimanfaatkan dengan baik oleh DPRD Kabupaten Batang. DPRD Kabupaten Batang lebih mengutamakan fungsi legislatif daripada fungsi pengawasan. $\mathrm{Hal}$ tersebut ditandai dengan DPRD Kabupaten Batang lebih berupaya agar kegiatan-kegiatan usulannya agar dapat mendapat pagu indikatif di RKPD 2016. Upaya tersebut dilakukan DPRD Kabupaten Batang karena selama ini DPRD tidak banyak mempunyai akses untuk dapat mempengaruhi program/kegiatan RKPD karena RKPD selama ini diyakini oleh eksekutif Kabupaten Batang sebagai wilayah khusus bagi eksekutif daerah, dalam kata lain bahwa wilayah perencanaan adalah wilayah eksekutif.

Akibatnya, Alokasi sumber daya dalam penganggaran tidak didasarkan pada analisis program dan kegiatan yang dihubungkan dengan tujuan yang telah ditetapkan. Temuan ini mengkonfirmasi penelitian Jones dan Pendlebury dalam bukunya Public Sector Accounting, 5th Edition, hal.60 menjelaskan informasi yang disajikan line item budgeting, gagal untuk mengidentifikasikan jumlah alokasi untuk belanja barang/jasa berdasarkan visi misi daerah dan gagal mengidentifikasi perencanaan kegiatannya. Alokasi penentuan anggaran berdasarkan penganggaran Incremental seperti yang dijelaskan Jones dan Pendlebury dalam bukunya Public Sector Accounting, 5th Edition, hal.64 bahwa penentuan anggaran didasarkan pada penerimaan dan pengeluaran/belanja tahunan yang direvisi, perhatian hanya difokuskan pada berapa perubahan marginal yang harus dibuat dari tahun ke tahun.

Hasil analisa dan identifikasi program/kegiatan yang didanai RKPD 2016 dengan Matrik tabel 6.3 RPJMD Kabupaten Batang 2012-2017 tentang keterkaitan Visi, Misi, sasaran dan tujuan pembangunan daerah, hasilnya hanya 30\% program kegiatan yang disepakati dalam PPAS yang sesuai dengan sasaran pembangunan Kabupaten Batang 2016 atau visi-misi RPJMD 2012-2017 Kabupaten Batang, meskipun dalam Bab III Prioritas Belanja Daerah PPAS dicantumkan matrik program prioritas daerah beserta indikator kinerja yang mengacu pada Visi Misi RPMD Kabupaten Batang 2012-2017.

\section{Tahap Pelaksanaan Anggaran}

Pengawasan pelaksanaan anggaran yang hanya didasarkan pada realisasi dibandingkan dengan anggarannya (serapan 
anggaran). Pola pengawasan yang demikian tanpa disadari telah melegitimasi kehendak penguasa, yaitu para elit kekuasaan yang ada dalam struktur pemerintah daerah maupun legislatif. Pelaksanaan fungsi pengawasan, belum memperhatikan dengan baik terhadap penilaian terhadap konsistensi pelaksanaan kebijakan sejak proses penyusunan anggaran sampai dengan pelaksanaan dan pertanggungjawaban.

Selain itu, Implementasi pengawasan APBD oleh DPRD pada tahap pemanfaatan anggaran mayoritas adalah pengawasan teknis fungsional yang membutuhkan skill dan pengetahuan teknis di bidang atau urusan yang diawasi. Seringkali pengetahuan SKPD terhadap hal tersebut masih jauh dibawah SKPD yang menangani pelaksanaan APBD dibidang tersebut, dampaknya pada saat pengawasan, DPRD tidak dapat menemukan bukti yang akurat untuk dapat menindaklanjuti hasil temuannya. Untuk itu dibutuhkan keterbukaan informasi dari SKPD terkait agar pelaksanaan APBD dapat sesuai dengan perencanaan yang ditetapkan.

\section{Tahap Evaluasi}

Pada tahap evaluasi atau laporan adalah di mana saatnya kepala daerah menyampaikan laporan keterangan pertanggungjawaban (LKPJ) di hadapan DPRD Kabupaten Batang. Sesuai dengan aturannya pada saat LPKJ ini, DPRD Batang tidak berposisi untuk menolak atau menerima LKPJ Kepala Daerah Kabupaten Batang 2016, DPRD Kabupaten Batang membahas LKPJ 2016 sebagai laporan akhir

tahun 2016 perkembangan pelaksanaan pembangunan daerah.

Dalam menjalankan pengawasan pada tahap evaluasi, DPRD Kabupaten Batang sebagai lembaga politik menjalankan fungsi pengawasan pengawasan politik yang bersifat strategis yang memberikan rekomendasi atas pencapaian pembangunan pada tahun 2016 agar dapat diperbaiki dalam periode anggaran selanjutnya. Laporan Keterangan Pertanggungjawaban (LKPJ) Kepala Daerah kepada Dewan Perwakilan Rakyat Daerah merupakan salah satu wujud akuntabilitas, transparansi dan pertanggungjawaban pemerintah atas amanat yang diberikan masyarakat kepadanya, sekaligus sebagai wujud pengawasan DPRD terhadap pelaksanaan pembangunan di daerah. Tujuannya mengetahui keberhasilan atau kegagalan pemerintahan daerah dalam menjalankan tugasnya selama periode Tertentu, Peningkatan efisiensi, efetifitas, produktifitas dan akuntabilitas penyelenggaraan Pemerintah Daerah melalui Pengawasan DPRD Esensinya Kepala Daerah menyampaikan deskripsi kinerja yang telah dicapai selama kurun waktu satu tahun, kemudian hasilnya menjadi landasan bagi upaya perbaikan dan koreksi agar pelaksanaan program pemerintahan dan pembangunan di masa yang akan datang dapat lebih optimal.

\section{Faktor-Faktor yang mempengaruhi}

Efektifitas suatu peraturan maupun kebijakan akan sangat diperngaruhi oleh berbagai faktor 
pendukungnya, Soerjono Soekanto menyebutkan beberapa faktor sebagai berikut: (Soekanto, 2002)

1. Faktor hukumnya sendiri,

2. Faktor penegak hukum, yakni pihak-pihak yang membentuk maupun menerapkan hukum,

3. Faktor sarana atau fasilitas yang mendukung penegak hukum,

4. Faktor masyarakat, yakni lingkungan dimana hukum tersebut berlaku atau diterapkan.

\section{Faktor Hukum}

Produk hukum yang mengatur fungsi pengawasan DPRD terhadap jalannya penyelenggaraan pemerintahan daerah utamanya pengawasan pelaksanaan APBD telah dirumuskan secara jelas, tegas, sistematis dan tidak menimbulkan multi penafsiran. Produk hukum tersebut telah secara efektif mengatur fungsi pengawasan DPRD terhadap pelaksanaan APBD dalam kontek hubungan antara DPRD dan eksekutif sebagai mitra yang setara dalam merumuskan kebijakan daerah. Fungsi pengawasan pelaksanaan APBD tidak lagi bisa dan digunakan sebagai sarana impeachment atau menjatuhkan kepala daerah dari jabatannya. Hubungan antara DPRD dan kepala daerah bersifat saling mengisi kebijakan yang lebih baik untuk kepentingan konstituen dan masyarakat. Meskipun terjadi dinamika yang komplek dalam pelaksanaan pengawasan pelaksanaan APBD namun tidak terjadi deadlock, keterlambatan penetapan APBD atau bahkan pemerintah daerah menghentikan aktifitas pelayanan masyarakat (Government Shutdown)

Evaluasi kinerja bidang anggaran yang sudah dilakukan oleh anggota DPRD Batang dengan memanfaatkan Alat Kelengkapan Dewan yang terkait dalam menjalankan fungsi anggarannya sudah berjalan cukup optimal, artinya bahwa anggota dewan DPRD Kabupaten Batang bersama-sama Pemerintah Daerah Kabupaten Batang telah melaksanakan fungsi anggarannya dalam hal membahas dan menyetujui RAPBD. Dalam pembahasan RAPBD dan Penyetujuan RAPBD Kabupaten Batang antara Pemerintah Daerah dan DPRD Kabupaten Batang, tidak ditemukan kendala yang signifikan kalau kedua belah pihak saling memahami kepentingan masing-masing (sharing-profit) sehingga proses pembahasan dan penetapan RAPBD menjadi APBD berlangsung lancar.

Dengan demikian pelaksanaan pengawasan APBD yang merupakan otorisasi perencanaanpembangunan(RPJPD/RPJMD/RKP D) telah dapat dijalankan dengan baik, hasil pengawasan DPRD Batang digunakan untuk rekomendasi dan perbaikan-perbaikan proses pnyususunan dokumen perencanaan dan penganggaran.

\section{Faktor Aparatur Penegak Hukum yang terkait}

Keputusan Presiden Nomor 74 Tahun 2001 Pasal (2) yang menyatakan bahwa pengawasan penyelenggaraan pemerintahan daerah terdiri atas pengawasan fungsional, pengawasan 
legislatif, dan pengawasan masyarakat. Akan tetapi persoalan yang sering dikeluhkan aparat pengawasan fungsional pemerintahan. Pengawasan keuangan daerah yang terbagi dalam beberapa jenis, yaitu pengawasan legislatif (DPRD), pengawasan fungsional eksternal dan internal pemerintah, pengawasan melekat (SPIP), dan pengawasan masyarakat, menyisakan adanya sektor yang mekanisme pengawasannya belum jelas aturan mainnya.

Koordinasi antar sesama lembaga pengawasan cenderung lemah yang ada di Kabupaten Batang. Hal ini tidak hanya lemahnya koordinasi antara lembaga-lembaga pengawasan internal dengan lembaga pengawasan eksternal, tapi juga antar sesama lembaga pengawas internal sendiri. Akibatnya, selain praktik pengawasan internal cenderung tumpang tindih, temuan lembaga pengawasan internal seringkali tidak sejalan dengan lembaga pengawas eksternal. Hal ini berdampak pada rendahnya efektivitas pengawasan. Padahal koordinasi pengawasan sangat diperlukan dalam upaya mendukung Good Governance secara keseluruhan (Puluhulawa, 2011). Sehingga dengan mengoptimalkan fungsi-fungsi yang melekat pada diri lembaga pengawas, maka akan menghasilkan produk pengawasan yang utuh atas kinerja pemerintah. Dan produk pengawasan ini akan dapat membantu baik pemerintah maupun DPRD dalam pelaksanaan Good Governance dan tugas-tugas yang diemban dalam rangka mencapai kesejahteraan dan kemakmuran

\section{Faktor Sarana Atau Fasilitas Yang Mendukung Penegak Hukum}

Sarana prasarana penegakan hukum belum digunakan secara baik dan benar dalam pelaksanaan APBD Kabupaten Batang. Seperti, Keberadaan akuntansi dalam sektor pemerintahan di Indonesia mulai terlihat sejak diberlakukannya UU No. 17 Tahun 2003 Tentang Keuangan Negara, khususnya sebagaimana yang tercantum dalam Pasal 30-32.

Jones dan Pendlebury dalam bukunya Public Sector Accounting, 5th Edition, hal.25 mengungkapkan bahwa akuntansi manajemen memegang peran krusial dengan menyediakan informasi yang diperlukan untuk mengoperasikan sistem perencanaan dan pengendalian. informasi akuntansi manajemen diperlukan pada tahap perencanaan untuk menentukan aktivitas-aktivitas apa yang akan dilakukan, dan sumber daya yang akan dibutuhkan. Informasi akuntansi manajemen juga dibutuhkan pada tahap pengendalian untuk mengukur seberapa efektif organisasi dalam mencapai tujuan, dan sejauh mana efisiensi penggunaan sumber daya telah dicapai

Fungsi akuntansi yang semestinya dapat berperan mengefektifkan setiap tahapan pengelolaan keuangan daerah belum dapat dimaksimalkan, pada tahapan perencanaan dan penganggaran misalnya, masih ditemukan tidak adanya skala prioritas yang terumuskan secara tegas dalam proses pengelolaan keuangan publik, ketidakterpaduan antara rencana kegiatan dengan kapasitas sumber daya yang dimiliki, 
maraknya irasionalitas pembiayaan kegiatan pemerintah, rendahnya efektivitas dan efisiensi penggunaan keuangan publik, anggaran pendapatan negara/daerah yang tidak effesien dan kesalahan dalam penyajian laporan keuangan yang diakibatkan karena kekeliruan dalam menetapkan pos anggaran.

Pada tahapan pelaksanaan juga demikian, masih ditemukan adanya transaksi keuangan yang tidak didukung bukti yang cukup, penggunaan langsung atas pendapatan daerah, ketidakhandalan data aset dan persediaan, terjadinya kesalahan pencatatan transaksi, ketidaktepatan penggunaan anggaran, kehilangan dana/barang, ketidaksesuaian data antara satu pihak dengan pihak lainnya serta keterlambatan penyusunan laporan keuangan.

Sedangkan dalam tahapan pengawasan, temuan hasil pengawasan yang sering disembunyikan oleh para pejabat masih sering dijumpai, mengakibatkan peran aparat pengawasan intern pemerintah belum efektif dalam menciptakan early warning system.

Fenomena ini mengindikasikan fungsi akuntansi sebagai alat perencanaan, pengendalian dan dasar pengambilan keputusan belum difungsikan secara maksimal. Hal ini diperparah lagi dengan kebiasaan melakukan meniru sistem dan prosedur pengelolaan keuangan, termasuk sistem pengendalian intern pemerintah (SPIP), yang mana karena penyusunannya tidak didasarkan pada informasi yang relevan dan andal, pemikiran realistik dan objektif, pertimbangan aspek biaya dan manfaat (cost and benefit), ketersediaan sumber daya manusia dan infrastruktur teknologi informasi serta kondisi geografis dan budaya masyarakat, mengakibatkan dalam tataran pelaksanaannya selalu mengalami kendala, bahkan di beberapa daerah sistem tersebut sulit untuk diimplementasikan, sehingga berdampak pada tidak berfungsinya akuntansi secara maksimal dalam mengefektifkan dan mengefisienkan penganggaran, pelaksanaan dan pengawasan APBD Kabupaten Batang.

\section{Faktor Masyarakat Yakni Lingkungan} Dimana Hukum Tersebut Berlaku Atau Diterapkan

Proses politik dalam penetapan APBD pada dasarnya merupakan sarana dalam mencapai tujuan pembangunan, dan rencana aksi pemerintah dalam memberikan pelayanan kepada masyarakat. Pelaksanaan musrenbang dalam proses perencanaan pembangunan daerah, cenderung dilakukan hanya untuk memenuhi proses formal yang didasarkan pada regulasi, bahkan terkesan sekedar proses ritual yang seolah-olah keterlibatan masyarakat dalam perencanaan pembangunan benar-benar telah terjadi. Kondisi seperti ini tentunya berdampak pada proses penganggaran pemerintah yang cenderung status quo, tidak responsif terhadap keinginan atau harapan masyarakat yang dinamis, sejalan dengan dinamika yang terjadi di lingkungan masyarakat. Penganggaran partisipatif dan diskursus good governance yang menjadi 
slogan pemerintah diera reformasi, mestinya menempatkan masyarakat tidak hanya sebagai obyek pembangunan, tetapi juga menjadikan mereka sebagai subyek pembangunan.

Kedudukan legislatif sebagai unsur penyelenggara pemerintah daerah dan sekaligus sebagai wakil masyarakat dalam struktur kekuasaan, tidak menganggap ini sebagai persoalan penting yang seharusnya mereka dorong, supaya mekanisme partisipasi masyarakat yang lebih efektif.

Dari hasil analisa lingkungan hukum pengawasan APBD di Kabupaten Batang ditemukan belum adanya mekanisme partsipasi masyarakat untuk pengawasan APBD dan belum terciptanya jajaring pengawasan APBD yang berhubungan dengan masyarakat. $\mathrm{Hal}$ ini berdampak sikap apatis masyarakat terhadap pelayanan pemerintah sudah sangat tinggi sehingga kontrol dari masyarakat kurang. Kurangnya kontrol dari masyarakat ini menyebabkan pelayanan publik yang diberikan oleh aparatur pemerintah dan juga oleh DPRD Kabupaten Batang semakin tidak maksimal. Peningkatan peran masyarakat dalam memberikan masukan dan kritikan terhadap eksekutif dan legislatif perlu untuk diperbaiki dengan memberikan pengetahuan dan menyediakan wadah penyaluran pendapat yang lebih luas.

Sistem perencanaan hanya merepresentasikan kebenaran yang didasarkan atas konsensus yang dibangun diantara unsur penyelenggara pemerintahan daerah, yang didalamnya legislatif dipandang sebagai representasi dari masyarakat. Dokumen perencanaan yang digunakan sebagai dasar bagi pemerintah daerah untuk menyusun APBD, dihasilkan melalui sistem yang telah didominasi oleh struktur kekuasaan. Kebenaran atas dasar konsensus yang mereka bangun (berdasarkan dokumen perencanaan), kemudian digunakan sebagai pijakan dalam mengalokasikan sumber daya publik dalam proses penganggaran, sekaligus menjadi pedoman dalam mengevaluasi pelaksanaan anggaran

\section{Faktor Budaya Hukum}

Penetapan dokumen perencanaan dan penganggaran di Kabupaten Batang belum Budaya penganggaran berbasis program kinerja Outcome. Indikator kinerja SKPD baik itu yang tertuang dalam Renstra, Renja, RKA masih didominasi pada indikator output bukan outcome.

Proses perencanaan dan penganggaran di Kabupaten Batang pada tahun 2016 masih didominasi pada pendekatan teknokratik, politik, dan top down, sedangkan proses perencanaan dan penganggaran yang bersifat bottom up yakni pelibatan partisipasi masyarakat masih belum diperhatikan dengan baik.

Asas efektifitas dan efisiensi ini belum diterapkan secara murni, karena dalam mekanisme penyusunan APBD banyak faktor yang mempengaruhi yaitu antara lain kepentingan politik dan kesiapan dari SKPD. Ketika suatu RAPBD disusun dan dibahas dalam rapat komisi 
dan fraksi, sering terjadi perubahan karena adanya kebijakan daerah dan kesiapan anggaran. Selain itu terjadi perubahan-perubahan karena kepentingan politik dan tidak terakomodirnya usulan-usulan dari SKPD. Dalam penyusunan APBD kepentingan real masyarakat tidak di kedepankan karena dalam penetapan pos anggaran seringkali bukan berbasis kebutuhan real tetapi berbasis kepentingan politik dan kekuasaan. Terjadi pemborosan, masih banyak anggaran yang dapat ditekan. Keadaan tersebut merupakan kesulitan dalam penerapan asas efektifitas dan efisiensi dalam proses penyusunan APBD. Aspek lain yang menjadi penghambat kurang di tempatkannya masyarakat dalam berpartisipasi dalam penyusunan dan pengawasan proses penetapan APBD, sehingga kebutuhan masyarakat sering di kesampingkan.

\section{E. Simpulan}

Dalam konteks otonomi daerah, DPRD bukanlah satu-satunya lembaga daerah yang berfungsi sebagai lembaga pengawasan pelaksanaan perda APBD. Di dalam Peraturan Pemerintah No 105 Tahun 2000 tentang Pengelolaan dan Pertanggungjawaban Keuangan Daerah. Pengawasan atas pelaksanaan APBD terdapat dua lembaga pemerintah daerah yang diberi mandat untuk mengawasi APBD yakni DPRD dan Lembaga Daerah yang dibentuk oleh Kepala Daerah (Inspektorat). Kemudian peraturan pemerintah tersebut dipertegas dengan Keputusan Presiden Nomor 74 Tahun 2001 tentang Tata Cara Penyelengaraan Pengawasan
Penyelengaraan Pemerintah Daerah pasal (2) yang menyatakan bahwa pengawasan penyelenggaraan pemerintahan daerah terdiri atas pengawasan fungsional, pengawasan legislatif, dan pengawasan masyarakat. Namun demikian Pengawasan DPRD Kabupaten Batang masih banyak didominasi pada pengawasan teknis-fungsional yang merupakan wilayah tugas pengawasan dari lembaga internal pemerintah baik pusat maupun daerah, seperti BPKP dan Inspektorat. Pengawasan politik yang menjadi esensi pengawasan DPRD Batang menjadi sedikit terabaikan yang menyebabkan pengawasan DPRD terhadap pelaksanaan Perda APBD menjadi tidak maksimal.

Faktor-faktor yang mempengaruhi pelaksanaan fungsi pengawasan DPRD terhadap Perda APBD adalah Faktor hukumnya sendiri, faktor penegak hukum, yakni pihak-pihak yang membentuk maupun menerapkan hukum, Faktor sarana atau fasilitas yang mendukung penegak hukum, dan Faktor masyarakat, yakni lingkungan dimana hukum tersebut berlaku.

\section{DAFTAR PUSTAKA}

\section{Buku}

Ibrahim, J. (2006). Teori dan Metodologi Penelitian Hukum Normatif. Malang : Bayu Publishing.

Schermerhorn, John R. (2002). Basic Organizational Behavior, USA : John Whiley and Sons Inc 
Jones, R., \& Pandlebury, M. (2000). Public Sector Accounting. 5th Edition. London : Pitman Publishing.

Stoner, James F., Freeman, R Edward., Gilbert, Daniel R. Management. New Jersey : Prentice Hall inc.

Marzuki, Peter M. (2011). Penelitian Hukum. Jakarta : Kencana Prenada Media Group

Soekanto, S. (2002). Faktor-Faktor yang Mempengaruhi Penegakan Hukum. Jakarta :PT. Raja Grafindo Persada.

\section{J urnal}

Aminudin. (2015). Fungsi Pengawasan DPRD Dalam Mewujudkan Tata Kelola Pemerintahan Yang Baik, e-Jurnal Katalogis, Vol.3, (No.12, Desember 2015), pp.132-141

Amalia, Luky S. (2011). Politik Pengawasan DPRD Dalam Upaya Pemakzulan Kepala Daerah : Studi Kasus Walikota Surabaya. J urnal Penelitian Politik LIPI, Vol.8, (No.1), pp. 53-70.

Andriana, N. (2014). Pemilu dan Relasi Eksekutif Dan Legislatif, Jurnal Penelitian Politik Vol.11 (No. 2 Desember 2014), pp.101-128 Budiyono. (2013). Pelaksanaan, Fungsi Pengawasan DPRD Terhadap Pemerintah Daerah Dalam Rangka Mewujudkan Good Governance. Fiat Justitia, Jurnal IImu Hukum Vol.7(No.1 J anuari-April 2013), pp. 1-12.
Fitriyah. (2010). Posisi DPRD Dalam UU No. 32 Tahun 2004. POLITIKA, Vol.I, (No.1), pp.84-103.

Lusiah., \& Rajagukguk, J. (2011). Pola Hubungan Eksekutif dan Legislatif Menurut UU Nomor 32 Tahun 2004 Dalam Hal Tugas dan Fungsi Anggaran. Visi Vol.19, (No.3), pp.652-666.

Nurhemi \& Suryani R, Guruh. (2015). Dampak Otonomi Keuangan Daerah Terhadap Pertumbuhan Ekonomi Di Indonesia, Buletin Ekonomi Moneter dan Perbankan, Vol.18, (No. 2, O ktober 2015), pp.183-206.

Puluhulawa, Fenti U. (2011). Pengawasan Sebagai Instrumen Penegakan Hukum. J urnal Dinamika Hukum Vol.11, ( No. 2 Mei 2011), pp.306-315.

Suryanto. (2010). Implikasi Implementasi

Kebijakan Desentralisasi dan Otonomi Daerah Terhadap Hubungan Keuangan Pusat - Daerah. Jurnal Pusat Kajian Kinerja Otonomi Daerah - Lembaga Administrasi Negara (PKKOD-LAN), 2010.

Kumorotomo, W. (2007). Memperbaiki Mekanisme Kawal dan Imbang (Checks And Balances) dalam Sistem Pemerintahan Daerah. Jurnal Kebijakan dan Administrasi Publik (J KAP) VOL.11, (N0.1), pp.63-85.

\section{Peraturan Perundang Undangan}

Undang Undang Dasar 1945

Undang-Undang No.25 tahun 2004 tentang Sistem Perencanaan Pembangunan Nasional (SPPN) 
Jurnal Law Reform

Volume 14, Nomor 2, Tahun 2018

Undang-undang Nomor 23 tahun 2014, tentang

Pemerintahan Daerah. Peraturan Menteri

Dalam Negeri No. 13, Tentang Pengelolaan

Keuangan Daerah.

Undang-Undang Nomor 15 tahun 2004 tentang

Pemeriksaan atas Pengelolaan dan

Tanggung Jawab Keuangan Negara

Undang-undang Nomor 27 Tahun 2009 tentang

Majelis Permusyawaratan Rakyat, Dewan

Perwakilan Rakyat, Dewan Perwakilan

Daerah, dan Dewan Perwakilan Rakyat

Daerah

UU 23 tahun 2014 tentang Pemerintahan Daerah

UU 32 tahun 2004 tentang Pemerintahan Daerah

Peraturan Pemerintah No. 25 tahun 2014 tentang

Pedoman Penyusunan Peraturan Tata

Tertib Dewan Perwakilan Rakyat Daerah.

Keputusan Presiden Nomor 74 Tahun 2001

Permendagri No. 54 tahun 2010 tentang

Pelaksanaan PP No. 98 tahun 2008

Tentang Tahapan, Tata Cara Penyusunan

Pengendalian dan Evaluasi Pelaksanaan

Rencana Pembangunan Daerah

Tata Tertib DPRD Kab. Batang No. 1 tahun 2014

\section{Website}

http://www.bpkp.go.id/puslitbangwas/konten/2674/

16.050-Faktor-Faktor-Penyebab-Kepala-

Daerah-Korupsi, diakses 16 Juni 2018 